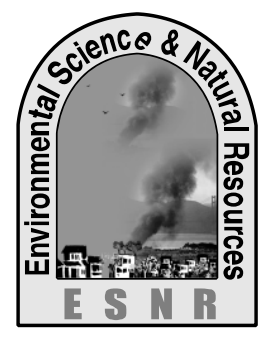

\title{
Studies on the Proximate Composition, Quality and Heavy Metal Concentration of two Sun-Dried Marine Fish (Sun-Dried Silver Pomfret and Sun-Dried Perch) of Cox's Bazar District of Bangladesh
}

\author{
M. N. Hossain ${ }^{1}$, M. G. M. Jamil ${ }^{2}$, M. M. Mia ${ }^{1}$, M. N. Uddin ${ }^{2}$ and M. A. Mansur ${ }^{2 *}$ \\ ${ }^{1}$ Department of Fisheries, Ministry of Fisheries and Livestock, Government of the People's Republic \\ of Bangladesh, \\ ${ }^{2}$ Department of Fisheries Technology, Faculty of Fisheries, Bangladesh Agricultural University, \\ Mymensingh-2202 \\ * Corresponding author: mansurft63@gmail.com
}

\begin{abstract}
This research was conducted on the proximate composition, quality aspect and heavy metal concentration of sun-dried Silver Pomfret (Stromateus cinereus) and sun-dried Perch (Lates calcarifer) which were collected from local market of Cox's Bazar town. These sundried marine fishes were collected from the stock after first drying procedure. Organoleptically most of these sun-dried fishes were in 'excellent' grade some were in 'Good' grade. Crude Protein, Lipid, Moisture, Ash, TVB-N and TMA-N content (\%) of sun-dried Silver Pomfret (Stromateus cinereus) was 32.25 $\pm 1.50,7.75 \pm 0.20$, 39.59 $\pm 0.34,15.75 \pm 0.39$, 85.68 \pm 1.60 and $8.41 \pm 0.37$ respectively. Whereas in sun-dried Perch (Lates calcarifer) the content (\%) of Crude Protein, Lipid, Moisture, Ash, TVB-N and TMA-N was $40.31 \pm 2.13,5.03 \pm 0.55,26.74 \pm 0.47,11.50 \pm 0.26,46.97 \pm 1.00$ and $8.21 \pm 0.12$ respectively. Heavy metal concentration i.e. Cd, Cr, Pb, $\mathrm{Cu}$ and $\mathrm{Zn}$ concentration (ppm) in sun-dried Silver Pomfret (Stromateus cinereus) was 0.68, 5.85, 8.43, 1.15, 24.93 ppm. Whereas heavy metal concentration (ppm) in sun-dried Perch (Lates calcarifer) was Cd 0.65 ppm, Cr 5.6 ppm, Pb 6.28 ppm, Cu 1.04 ppm, Zn $23.8 \mathrm{ppm}$.
\end{abstract}

Key words: Heavy metal, Proximate composition, Quality and Sun-dried marine fish

\section{Introduction}

Sun-drying of fish is most widely practiced method of fish preservation in Bangladesh. Every year a sizeable quantity of freshwater fish and marine fish are preserved by sun-drying for domestic consumption as well as for export. Sun-drying is practiced for fish preservation because this method is simple, easy and does not require sophisticated apparatus. Sun-dried marine fishes are very delicious and liked by people at home and abroad. A considerable portion of total production of sun-dried fish is exported to international market every year to fulfill consumers' demand. Horner (1992) stated that drying being a curing process, as a means of preserving fish, has been practiced perhaps longer than any other food preservation techniques. Marine fish bones found in cave dwellings, inhabited 20000 years ago and situated many days walk from the coast of Spain, indicate some form of curing, probably by drying in the open air. Drying, like other curing processes, has continued as preservation techniques virtually unaltered from prehistory to the present day. Modern developments have centered around understanding and controlling the processes to achieve the standardized product demanded by today's market.

In Bangladesh fish is the major source of animal protein, essential amino acids, lipid, essential fatty acids, DHA, EPA, $\omega-3$ PUFA, minerals, vitamin, antioxidants. Marine fishes are good export earning commodity in Bangladesh. Marine fish and fishery products i.e. marine fisheries contribute to GDP, livelihood of many people (10\% of population directly or indirectly dependent on inland fisheries and marine fisheries), employment of 0.3 million people in Bangladesh (DoF, 2015). To find the nutritional benefit of marine fish and fishery product we should consider quality, it should be safe to eat and should be caught from unpolluted and unsuspected water area. A sizeable quantity of sun-dried marine fish is exported from Bangladesh every year. So it is important to know the quality and safety aspect of sun-dried marine fish of Bangladesh.

Attractive sensory properties (flavour, taste, colour, texture) and nutritional composition of sun-dried marine fishes are the main cause of consumers' preference. Normally the sun-dried fishes possess higher protein content and mineral content. However due to pollution of aquatic environment and unawareness of the processors sometimes low grade fishes are sun-dried. Even the raw fishes are partially decomposed before the beginning of sun-drying. Sometimes raw fish are harvested from polluted water. As a result the finished product is sometimes of low quality and unsafe for human consumption/health. Traditional method and slow drying rate cause a considerable degree of spoilage and consequently the low quality and shorter shelf life of the sun-dried product (Mansur et al., 1990). Quality and safety aspect of fish and fishery products has received considerable attention. Dried fish is also under such attention. Quality and safety aspect of sun-dried marine fishes need to be elucidated. This is important for the protection of consumers' health as well as for continuing export to international concentration of freshwater fish, marine fishes and fishery products of Bangladesh (Mansur et al., 2013; 2014; 2016 \& 2017; Pravakar et al., 2013). The present research was conducted on sun-dried marine fish. Objective of the present research was determination of sensory quality, nutritional composition (Protein, Lipid, Ash, Moisture). Such research is important and expected to contribute in producing reliable data and information. Such data and information will be helpful to develop effective Quality Control and Assurance Programme as well as to produce a safe product for export, and domestic consumption. 


\section{Materials and Method}

\section{Collection, transportation and storage of the sample}

Sun-dried Silver Pomfret ( $S$. cinereus) and sundried Perch (L. calcarifer) were bought from local market of Cox's Bazar town. Sundried fish samples were packed tightly in polyethylene bags and transported to the laboratory of the Department of Fisheries Technology, Bangladesh Agricultural University, Mymensingh-2202 by vehicle which required 24 hours. On arrival to the laboratory a portion of the samples were taken for sensory quality assessment. The rest of the samples were kept in plastic containers with air-tight lid. The plastic containers were stored at room temperature in the laboratory. Stored samples were used for consequent laboratory analysis.

\section{Sensory quality assessment}

Sensory quality as for example colour, odour, taste and texture of sun-dried Silver Pomfret (S. cinereus) and sun-dried Perch (L. calcarifer) was conducted by organoleptic method of Howgate et al. (1992). In doing so the SDP (Score of Defect Points) was calculated first. Then Grading was done according to the recommended Table shown below.

\section{Bio-chemical analysis}

Proximate composition (Protein, Lipid, Ash, Moisture), TVB-N and TMA-N of the sundried fish samples were estimated according to the method of A.O.A.C (1965) and AMC (1979). All determinations were done in triplicate and the average value was reported mentioning the standard deviation. In doing so, slight modification/change in the use of apparatus was followed during this research.

\section{Heavy metal analysis}

Sample preparation for heavy metal analysis The sun-dried fish were chopped and finely homogenized (ground) with a blender. In this way sample was

Table 1. Score of defect points

\begin{tabular}{|l|l|l|l|}
\hline Characteristics & Defect characteristics & Defect point & Grade \\
\hline \multirow{4}{*}{$\begin{array}{l}\text { Use of } \\
\text { chemicals }\end{array}$} & Nothing & 1 & Acceptable \\
\hline \multirow{4}{*}{ Color } & Nogos, DDT & 5 & Rejected \\
\cline { 2 - 4 } & Off white and clear Yellowish & 1 & Excellent \\
\cline { 2 - 4 } & Brownish to yellowish & 2 & Acceptable \\
\cline { 2 - 4 } & Reddish & 3 & Acceptable \\
\cline { 2 - 4 } & Brownish in outer and reddish in inside & 5 & Rejected \\
\hline \multirow{5}{*}{ Odor } & Natural & 1 & Excellent \\
\cline { 2 - 4 } & Characteristic odor & 2 & Acceptable \\
\cline { 2 - 4 } & Slightly sour & 3 & Acceptable \\
\cline { 2 - 4 } & Sour & 5 & Rejected \\
\hline \multirow{4}{*}{$\begin{array}{l}\text { Brokture } \\
\text { pieces }\end{array}$} & Firm and flexible & 1 & Excellent \\
\cline { 2 - 4 } & Soft & 2 & Acceptable \\
\cline { 2 - 4 } & Soft and damp & 5 & Rejected \\
\hline \multirow{5}{*}{ Infestation } & Nil & 1 & Excellent \\
\cline { 2 - 4 } & Slightly broken & 2 & Acceptable \\
\cline { 2 - 4 } & Broken & 5 & Rejected \\
\cline { 2 - 4 } & No infestation & 1 & Excellent \\
\cline { 2 - 4 } & Slightly infestation & 2 & Acceptable \\
\cline { 2 - 4 } & Infested by insects & 3 & Acceptable \\
\cline { 2 - 4 } & Infested by flies and insects & 5 & Rejected \\
\hline
\end{tabular}

Calculation of Score of Defect Points (SDP)

$$
\begin{aligned}
& \text { ¿DP Here, } \\
& \mathrm{SDP}=\frac{\Sigma D P}{n} \quad \text { SDP=Score of defect point } \\
& \sum \mathrm{DP}=\text { Summation of defect point } \\
& n=\text { Number of characters }
\end{aligned}
$$

Table 2. Grading of the fishery products

\begin{tabular}{|l|l|l|}
\hline Grade & Defect Points & Degree of freshness \\
\hline A & $<2$ & Excellent/Acceptable \\
\hline B & 2 to $<5$ & Good/Acceptable \\
\hline C & 5 & Reject \\
\hline
\end{tabular}

prepared from each sun-dried fish. Approximately 5g homogenized (ground) sample was taken in a crucible and dried at $105^{\circ} \mathrm{C}$ for 24 hours in an electric oven. This dried sample was used for heavy metal analysis.

\section{Sample digestion}

Accurately weighed $0.5-1.0 \mathrm{~g}$ oven dried sample was taken in a Micro-Kjeldahl flask. A volume of $10 \mathrm{ml}$ nitric acid was added to this flask. After that $5 \mathrm{ml}$ perchloric acid was added to this flask. The Micro- 
Kjeldahl flask containing the sample and acid mixture was placed in an Electrothermal heater and heated at $30^{\circ}-80^{\circ} \mathrm{C}$. Heating started at $30^{\circ} \mathrm{C}$ and gradually heating temperature was increased to $80^{\circ} \mathrm{C}$. During heating the colour of the liquid in flask (sample + acid mixture) was turned into reddish colour, which was turned into white colour afterwards. Then the flask with the contents was cooled. Then $6 \mathrm{~N} 6 \mathrm{ml} \mathrm{HCl}$ was added to the flask. The Micro-Kjeldahl flask with its contents was placed in the Electrothermal heater and heated at $30^{\circ}-80^{\circ} \mathrm{C}$. Heating temperature gradually increased from $30^{\circ} \mathrm{C}$ to $80^{\circ} \mathrm{C}$. This time the colour of the liquid (sample + acid) in flask was first yellow colour which was turned into white colour afterwards. Then the flask with its content was cooled. The content of the flask was taken in a $50 \mathrm{ml}$ volumetric flask. The volume was made up to the mark $(50 \mathrm{ml})$ by distilled water according to Eboh et al. (2006). This solution was filtered by ash less. Whatman No.1 filter paper.

\begin{abstract}
Atomic Absorption Spectrophotometric Analysis
This digested solution was then subjected to Atomic Absorption Spectrophotometric analysis according to the method of Clesceri et. al. (1989). The absorbance of the colour of the solutions was measured by Atomic Absorption Spectrophotometer at a specific wave length. The wave length for such measurement was for As, $\mathrm{Cr}$ and $\mathrm{Cd}$ was 193.7, 127 and $217 \mathrm{~nm}$, respectively. The absorbance and corresponding concentration of heavy metal was observed or determined from a standard graph which was previously prepared by standard compound of heavy metal.
\end{abstract}

\section{Calculation}

The actual concentration of heavy metal was calculated by the following formula:

Heavy Metal Concentration $(\mathrm{ppm})=\frac{\text { ppm conc. observed } \times \text { final vol. of sample in } \mathrm{ml}}{\text { Weight of tissue taken in } \mathrm{g}}$

\section{Result and Discussion}

This research was conducted to determine the proximate composition (Protein, Lipid, Ash, Moisture), TVB-N, TMA-N, Hevay Metal particularly Cd, Cr, Pb, $\mathrm{Cu}$ and $\mathrm{Zn}$ of two sundried marine fish e.g. Sun dried Silver Pomfret (Stromateus cinereus) and Sun-dried Perch (Lates calcarifer). Result of the present research is presented below.

\section{Sensory quality}

Result of the sensory quality assessment has been presented in Table 1. Colour of some samples were slightly brown, some were brown to dark brown compared with freshly prepared samples which is expected to have an attractive cream colour. Slightly rancid odour and bitter taste was developed in some samples. It appears that moisture content of the sundried marine fish samples was comparatively higher which resulted certain degree of deteriorative changes as a result slightly browning, slightly rancidity and slightly off odour developed in some samples. Texture was hard but not firm in most of the samples. Overall sensory quality of most of the samples were of excellent grade, some were in good grade.

\section{Proximate composition}

Proximate composition of sun dried Pomfret ( $S$. cinereus) and sun-dried Perch (L. calcarifer) has been presented in Table 4. Protein content (\%) of fish and fishery products is most important from nutritional point of view. The protein content (\%) of sun-dried Silver Pomfret ( $S$. cinereus) and sun-dried Perch $(L$. calcarifer) was $32.25 \pm 1.50$ and $40.31 \pm 2.13$ respectively. The lower value was in sun-dried Silver Pomfret and the higher value was in sun-dried Perch. Result of the present research is close to the results of Chakraborty et al. (1997). Sometimes protein content of sun-dried marine fishes are higher than the result of present study. Over drying of marine and Sun-dried Perch (Lates calcarifer) fish sample sometimes result in higher protein content than the result of present research.

Table 3. Organoleptic characteristics of Sun dried Silver Pomfret (Stromateus cinereus)

\begin{tabular}{|l|l|l|l|l|l|}
\hline \multicolumn{1}{|c|}{ Sample } & Colour & Odour & Texture & Broken Pieces & Overall Quality \\
\hline $\begin{array}{l}\text { Sun dried } \\
\text { Silver Pomfret } \\
\text { Stromateus } \\
\text { cinereus) }\end{array}$ & $\begin{array}{l}\text { Slightly brown } \\
\text { in most of the } \\
\text { samples; } \\
\text { brown to dark } \\
\text { brown in some } \\
\text { samples }\end{array}$ & $\begin{array}{l}\text { Slightly } \\
\text { rancid } \\
\text { odour }\end{array}$ & $\begin{array}{l}\text { Hard (but } \\
\text { not elastic) }\end{array}$ & $\begin{array}{l}\text { Small broken } \\
\text { pieces detected } \\
\text { which indicates } \\
\text { over drying of } \\
\text { some samples }\end{array}$ & $\begin{array}{l}\text { Excellent in most } \\
\text { samples; } \\
\text { Good in some } \\
\text { samples }\end{array}$ \\
\hline $\begin{array}{l}\text { Sun-dried } \\
\begin{array}{l}\text { Perch (Lates } \\
\text { calcarifer) }\end{array}\end{array}$ & $\begin{array}{l}\text { Slightly brown } \\
\text { in most of the } \\
\text { samples; } \\
\text { brown to dark } \\
\text { brown in some } \\
\text { samples }\end{array}$ & $\begin{array}{l}\text { Slightly } \\
\text { rancid } \\
\text { odour }\end{array}$ & $\begin{array}{l}\text { Hard (but } \\
\text { not elastic) }\end{array}$ & $\begin{array}{l}\text { Few broken } \\
\text { pieces were } \\
\text { observed }\end{array}$ & $\begin{array}{l}\text { Excellent in most } \\
\text { samples; Good in } \\
\text { some samples }\end{array}$ \\
\end{tabular}


The lipid content (\%) of sun-dried Silver Pomfret $(S$. cinereus) was 6.75 \pm 0.20 and sun-dried Perch ( $L$. calcarifer) was $5.03 \pm 0.55$. Higher value was obtained in sun-dried Silver Pomfret (S. cinereus). Result of the present research is close to the results of previous research by Siddique and Akter (2011) and Bhuiyan (1992) wher the lipid content of sun-dried marine fishes was ranged from $5.86 \%$ to $7.78 \%$ and $6.84 \%$ to $9.21 \%$.

Table 4. Proximate composition of Sun dried Silver Pomfret (S. cinereus) and Sun-dried Perch (L. calcarifer)

\begin{tabular}{|c|c|c|}
\hline Parameter & Sun-dried Silver Pomfret & Sun-dried Perch \\
\hline Protein (\%) & $32.25 \pm 1.50$ & $40.31 \pm 2.13$ \\
\hline Lipid (\%) & $6.75 \pm .020$ & $5.03 \pm 0.55$ \\
\hline Ash (\%) & $15.73 \pm 0.39$ & $11.5 \pm 0.26$ \\
\hline Moisture (\%) & $39.59 \pm 0.34$ & $26.74 \pm 0.47$ \\
\hline
\end{tabular}

Ash content (\%) of sun-dried Silver Pomfret $(S$. cinereus) and sun-dried Perch (L. calcarifer) was $15.73 \pm 0.39$ and $11.5 \pm 0.26$. Higher value was obtained in sun-dried Silver Pomfret (S. cinereus). Result of ash content is expected and acceptable depending on the previous research and literature. Moisture content (\%) of sun-dried Silver Pomfret (S. cinereus) and sun-dried Perch (L. calcarifer) was $39.59 \pm 0.34$ and $26.74 \pm 0.47$ respectively. Higher moisture content was obtained in sun-dried Silver Pomfret ( $S$. cinereus). The moisture content of the sun-dried marine fishes was slightly higher than expectation. Two reasons may lay behind it. First reason is that the sun-dried marine fishes were collected after first year of storage. During this time the products absorbed moisture from the atmosphere. The second reason is that the traders keep the sun-dried marine fishes in wet and inhygienic condition and do not control the moisture and air temperature of the warehouse. Proximate composition e.g. Protein, Lipid, Ash, Moisture of the sun-dried fishes will be different because the proximate composition of raw fishes varies from species to species and even within the same species from one individual to another due to geographical distribution, age, sex, season, $\mathrm{pH}$, size. But the primary cause is the food intake and the degree of energy expenditure. Knowledge on proximate composition is very important for evaluating the nutritive value/nutritional quality of fish and fishery products. In industrial processing knowledge of proximate composition is important to know the yield, to know the protein, lipid and moisture content to preserve fish by correct process, to know the mineral content for product development. In addition seasonal variation of oil content of fish, composition of oil and difference in composition between male and female fish are of chemical and physiological interest. The muscle of fishes and other aquatic animal enfolds a variety of constantly changing interactive systems. The balance between these systems can vary widely without causing death of fish but after capture and killing the variations often influence the acceptability of fish as food for human consumption. They also affect its suitability for processing. That means such variation has important effect on quality. From nutritional point of view protein supplies energy in human cell, possess anti-oxidant activity, helps many biological functions e.g. antimutagenicity, antiaging. It is flavour binder of food in presence of moisture. Lipid is the most concentrated form of energy stored in fish, active species carry more lipid than less-active species (Love, 1992). The beneficial substances in fish lipids are $\omega-3$ PUFA particularly EPA, DHA. Fish lipid supplies energy in human cell, lowers cholesterol level in human body. DHA and EPA are essential for human cell. DHA, EPA have anti-stress effect, helps brain maturity, effective against coronary heart disease. Ash content indicates the mineral content. Food which possesses low quantity mineral is usually recommended for patients with heart trouble, therefore the minerals present in the edible part of fish and fishery products is of interest.

\section{Total Volatile Base Nitrogen (TVB-N)}

Total Volatile Base Nitrogen (TVB-N) of sun-dried Silver Pomfret ( $S$. cinereus) and sun-dried Perch $(L$. calcarifer) has been presented in Table 5 TVB-N value for sun-dried Pomfret (S. cinereus) and sun-dried Perch (L. calcarifer) was $85.68 \pm 1.60$ and $46.97 \pm 1.00 \mathrm{mg} / 100$ $\mathrm{g}$ respectively. This result is within the acceptable range as recommended by Connell (1980).

Table 5. Total Volatile Base Nitrogen (TVB-N) of sun-dried Silver Pomfret (S. cinereus) and sun-dried Perch $(L$. calcarifer)

\begin{tabular}{|l|l|l|}
\hline Species (Product type) & TVB-N (mg/100g) & MAL* $(\mathrm{mg} / 100 \mathrm{~g})$ \\
\hline Sun-dried Silver Pomfret & $85.68 \pm 1.60$ & 100.00 \\
\cline { 1 - 2 } Sun-dried Perch & $46.97 \pm 1.00$ & \\
\hline
\end{tabular}

*MAL = Maximum Allowable Limit

TVB-N expresses the degree of spoilage caused by enzymes and bacteria. Quality in terms of retaining inherent freshness is indicated by the parameter TVB$\mathrm{N}$. Now-a-days importance is given to the TVB-N of 
raw fish and a maximum allowable limit is set. This maximum allowable limit determines the acceptability and safety of fish and fishery products. Fresh fish muscle contains a little TMAO but the major portion of the Total Volatile Base Nitrogen is considered essentially to be ammonia. In fish sample ammonia originates from amino acids, mainly from glutamine and probably also from asparagine. Selection of appropriate method for accurate determination of TVB$\mathrm{N}$ is important. Literature suggests that a number of methods for TVB-N determination have been proposed by many researchers (Miller et al., 1972; Keay and Hardy, 1972; Murray and Gibson, 1972; Gruger, 1972; Ritskes, 1975; Ruiter and Weseman, 1976; Ward et al., 1979; Parris, 1984; Bhotta et al., 1984).

In this research sample extraction with trichloro acetic acid and steam distillation method was chosen because sophisticated method was considered impractical for routine monitoring. In addition, steam distillation method was found most reliable which is the recommended general method by the Analytical Methods Committee. This method was selected to obtain accurate result of TVB-N determination of marine fishes. The TVB-N of the sun-dried marine fishes is higher than the TVB-N of cold water herring and mackerel of Britain. TVB-N content of fresh chilled
Herring (Clupea harengus) and Mackerel (Scomber scombrus) was $7.48 \pm 0.86 \mathrm{mg} / 100 \mathrm{~g}$ and $9.0 \pm 0,90$ $\mathrm{mg} / 100 \mathrm{~g}$ respectively, and TVB-N content of pickled herring was $75.87 \pm 1.62 \mathrm{mg} / 100 \mathrm{~g}$, and in heavily salted mackerel TVB-N content was $16.0 \pm 1.14 \mathrm{mg} / 100 \mathrm{~g}$. (Mansur, 1995).

\section{Tri- Methyl Amine Nitrogen (TMA-N)}

Tri-methyl Amine Nitrogen (TMA-N) of sun-dried Silver Pomfret (Stromateus cinereus) and sun-dried Perch (Lates calcarifer) has been presented in Table 6 Tri-methyl Amine Nitrogen (TMA-N) of sun-dried Pomfret (Stromateus cinereus) and sun-dried Perch (Lates calcarifer) was $9.41 \pm 0.37$ and $8.21 \pm 0.12$ respectively. This value is within the acceptable limit. In the previous research it was found that the TMA-N content of pickled herring (Clupea harengus) and heavily salted mackerel (Scomber scombrus) was $6.2 \pm 1.73 \mathrm{mg} / 100 \mathrm{~g}$ and $12.0 \pm 2.16 \mathrm{mg} / 100 \mathrm{~g}$. TMA-N indicates the bacterial spoilages takes place in fish and fishery products. TMAO a naturally occurring compound in marine fishes in reduced to TMA by bacteria. Reduction in concentration of TMAO and increase in TMA has been used as chemical measure of spoilage. Reaction between TMA and fatty substances results ammoniacal fishy odour.

Table 6. Tri-methyl Amine Nitrogen (TMA-N) of sun-dried Silver Pomfret (S. cinereus) and sun-dried Perch $(L$. calcarifer)

\begin{tabular}{|l|l|l|}
\hline Species (Product type) & TMA-N $(\mathrm{mg} / 100 \mathrm{~g})$ & MAL* $(\mathrm{mg} / 100 \mathrm{~g})$ \\
\hline Sun-dried Silver Pomfret & $9.41 \pm 0.37$ & $10-15$ \\
\cline { 1 - 2 } Sun-dried Perch & $8.21 \pm 0.12$ & \\
\hline
\end{tabular}

* MAL = Maximum Allowable Limit

\section{Heavy metal concentration}

Result of heavy metal (metal and elements) analysis for determination of concentration in the sun-dried Silver Pomfret (S. cinereus) and sun-dried Perch ( $L$. calcarifer) has been presented in the Tables 5 to 9 . Among the heavy metals the concentration of $\mathrm{Cd}, \mathrm{Cr}$, $\mathrm{Pb}, \mathrm{Cu}$ and $\mathrm{Zn}$ was determined during this research.

Table 7. Cadmium $(\mathrm{Cd})$ concentration in the sun-dried Silver Pomfret (S. cinereus) and in the sun-dried Perch $(L$. calcarifer)

\begin{tabular}{|l|l|l|}
\hline Species (Product type) & Cd concentration $(\mathrm{ppm})$ & MAL* $(\mathrm{ppm})$ \\
\hline Sun-dried Silver Pomfret & 0.68 & \multirow{2}{*}{1.0} \\
\cline { 1 - 2 } Sun-dried Perch & 0.65 & \\
\hline
\end{tabular}

*MAL = Maximum Allowable Limit

Result of heavy metal analysis for determination of $\mathrm{Cd}$ concentration in the sun-dried Silver Pomfret $(S$. cinereus) and sun-dried Perch (L. calcarifer) has been presented in the Table $7 \mathrm{Cd}$ concentration in the sundried Silver Pomfret (S. cinereus) and sun-dried Perch
(L. calcarifer) was 0.68 and $0.65 \mathrm{ppm}$ respectively which is within the Maximum Allowable Limit (1.0 $\mathrm{ppm}$ ) as recommended by WHO. Cd is injurious to health. It cause chronic problem, renal disease in human if accumulated in the body.

Table 8. Chromium $(\mathrm{Cr})$ concentration in the sun-dried Silver Pomfret $(S$. cinereus $)$ and in the sun-dried Perch $(L$. calcarifer)

\begin{tabular}{|l|l|l|}
\hline Species (Product type) & Cr concentration $(\mathrm{ppm})$ & MAL* $(\mathrm{ppm})$ \\
\hline Sun-dried Silver Pomfret & 5.85 & \multirow{2}{*}{0.05} \\
\hline Sun-dried Perch & 5.60 & \\
\hline
\end{tabular}

*MAL = Maximum Allowable Limit

Result of heavy metal analysis for determination of $\mathrm{Cr}$ concentration in the sun-dried Silver Pomfret $(S$. cinereus) and sun-dried Perch (L. calcarifer) has been presented in the Table $8 \mathrm{Cr}$ concentration in the sundried Silver Pomfret (S. cinereus) and in the sun-dried Perch (L. calcarifer) was 5.85 and $5.60 \mathrm{ppm}$ 
respectively. This value is above the Maximum Allowable Limit $(0.05 \mathrm{ppm})$ as recommended by WHO. $\mathrm{Cr}$ also injurious to health. If eaten regularly with contaminated fish and fishery products $\mathrm{Cr}$ cause irreversible problem in stomach, renal disease, overall health risk.

Table 9. Lead $(\mathrm{Pb})$ concentration in the sun-dried Silver Pomfret $(S$. cinereus) and in the sun-dried Perch (L. calcarifer)

\begin{tabular}{|l|l|l|}
\hline Species (Product type) & Pb concentration $(\mathrm{ppm})$ & MAL* $(\mathrm{ppm})$ \\
\hline Sun-dried Silver Pomfret & 8.43 & 2.0 \\
\cline { 1 - 2 } Sun-dried Perch & 6.28 & \\
\hline
\end{tabular}

*MAL = Maximum Allowable Limit

Result of heavy metal analysis for determination of $\mathrm{Pb}$ concentration in the sun-dried Silver Pomfret ( $S$. cinereus) and sun-dried Perch (L. calcarifer) has been presented in the Table $9 \mathrm{~Pb}$ concentration in the sundried Silver Pomfret ( $S$. cinereus) and in the sun-dried Perch (L. calcarifer) was 8.43 and $6.28 \mathrm{ppm}$ respectively. This value is also above the Maximum Allowable Limit (2.0 ppm) as recommended by WHO. $\mathrm{Pb}$ is also injurious to health. Regular ingestion with contaminated fish and fishery products $\mathrm{Pb}$ cause renal disease, overall health risk and retarded growth in children.

Table 10. Copper $(\mathrm{Cu})$ concentration in the sun-dried Silver Pomfret (S. cinereus) and in the sun-dried Perch $(L$. calcarifer)

\begin{tabular}{|l|l|l|}
\hline Species (Product type) & Cu concentration $(\mathrm{ppm})$ & MAL* $(\mathrm{ppm})$ \\
\cline { 1 - 2 } Sun-dried Silver Pomfret & 1.15 & 10.0 \\
\cline { 1 - 2 } Sun-dried Perch & 1.04 & \\
\hline
\end{tabular}

*MAL = Maximum Allowable Limit

Result of heavy metal analysis for determination of $\mathrm{Cu}$ concentration in the sun-dried Silver Pomfret ( $S$. cinereus) and sun-dried Perch (L. calcarifer) has been presented in the Table $10 \mathrm{Cu}$ concentration in the sundried Silver Pomfret ( $S$. cinereus) and in the sun-dried Perch (L. calcarifer) was 1.15 and $1.04 \mathrm{ppm}$ respectively. This value is also above the Maximum Allowable Limit (10.00 ppm) as recommended by WHO. $\mathrm{Cu}$ cause unpleasant odour, unpleasant green colour which cause marketing problem of fish and fishery products as well as toxicological effect.

Table 11. Zink $(\mathrm{Zn})$ concentration in the sun-dried Silver Pomfret (S. cinereus) and in the sun-dried Perch (L. calcarifer)

\begin{tabular}{|l|l|l|}
\hline Species (Product type) & Zn concentration $(\mathrm{ppm})$ & MAL* $(\mathrm{ppm})$ \\
\hline Sun-dried Silver Pomfret & 24.93 & \multirow{2}{*}{100.0} \\
\cline { 1 - 2 } Sun-dried Perch & 23.8 & \\
\hline
\end{tabular}

*MAL = Maximum Allowable Limit

Result of heavy metal analysis for determination of $\mathrm{Zn}$ concentration in the sun-dried Silver Pomfret $(S$. cinereus) and sun-dried Perch (L. calcarifer) has been presented in the Table $11 \mathrm{Zn}$ concentration in the sundried Silver Pomfret ( $S$. cinereus) and in the sun-dried Perch (L. calcarifer) was 24.93 and $23.8 \mathrm{ppm}$ respectively. This value is within the Maximum Allowable Limit (100.00 ppm) as recommended by WHO. Zn also cause unpleasant odour, unpleasant colour which cause marketing problem of fish and fishery products as well as toxicological effect.

Among the heavy metal detected/determined in sundried Silver Pomfret (S. cinereus) and sun-dried Perch (L. calcarifer) during this research Chromium $(\mathrm{Cr})$ and Lead $(\mathrm{Pb})$ was above Maximum Allowable Limit as recommended by WHO. However the concentration of Cadmium $(\mathrm{Cd})$, Copper $(\mathrm{Cu})$ and Zink $(\mathrm{Zn})$ was within the Maximum Allowable Limit as recommended by WHO. A large number of potentially harmful metals and elements are known as pollutants despite $\mathrm{Hg}$ has been implicated in disease to man caused by eating fish and fishery products. Pollution from any metal or element may cause unsuspected hazards to man. The elements of most concern are cumulative poisons, that is, those that cause injury to health through progressive and irreversible accumulation in the body as a result of ingestion of repeated small amounts. These include $\mathrm{Hg}$, Cd, Pb, Se, As, Cu, Zn (Connell, 1975).

Many countries are now taking voluntary or mandatory action to reduce pollution of the aquatic environment with heavy metal for the the food safety of aquatic food particularly fish. Considering the effect of heavy metal on fish quality and safety the food regulatory and health authorities in some developed countries have taken serious view and adopted maximum allowable limit of harmful metals and elements. Usually the pollutants of metals and element category contaminate the raw fish. As a result the concentration of heavy metal per unit mass of processed fish and fishery products is also considerable. However in the present research the concentration of $\mathrm{Cd}, \mathrm{Cu}, \mathrm{Zn}$ was within the maximum acceptable limit, but the concentration of $\mathrm{Cr}$ and $\mathrm{Pb}$ was above the maximum allowable limit as recommended by World Health Organisation, WHO (2001). 
Present research was conducted to know the proximate composition, quality, heavy metal concentration of two sun-dried marine fish e.g. sun-dried Silver Pomfret $(S$. cinereus) and sun-dried Perch (L. calcarifer) collected from local market of Cox's Bazar. Result of the present research showed that most samples of the sun-dried fishes were excellent in terms of sensory quality, proximate composition, TVB-N, TMA-N. But the heavy metal concentration of these two sun-dried fishes indicated slightly different view. Concentration of $\mathrm{Cd}$, $\mathrm{Cu}, \mathrm{Zn}$ was within maximum allowable limit whereas the concentration of $\mathrm{Cr}, \mathrm{Pb}$ was above maximum allowable limit. This information is very important for the domestic consumers in Bangladesh as well as for International Market where sun-dried fishes are exported.

\section{Conclusions}

On the basis of the result of present research it may be concluded that these sun-dried marine fishes e.g. sundried Silver Pomfret (S. cinereus) and sun-dried Perch (L. calcarifer) are of excellent quality and safe except $\mathrm{Cr}$ and $\mathrm{Pb}$ concentration. The $\mathrm{Cr}$ and $\mathrm{Pb}$ concentration in sun-dried Silver Pomfret ( $S$. cinereus) and sun-dried Perch (L. calcarifer) is above maximum allowable limit.

\section{Acknowledgement}

This research was conducted by the financial support of Bangladesh Agricultural University, Mymensingh as part of a research project entitled "Studies on the Quality and Safety Aspect of Fish and Fishery Products of Bangladesh". BAURES Project No. 2015/13/BAU from July 2015 to June 2017 (Principal Investigator: Professor Dr. Md. Abul Mansur). Heavy metal analysis was done in Bangladesh Institute of Nuclear Agriculture (BINA), BAU, Mymensingh. This research was the part of M. S. Thesis of Mr. Nour Hossain in the Department of Fisheries Technology, Bangladesh Agricultural University, Mymensingh-2202, Bangladesh.

\section{References}

AMC (Analytical Methods Committee). 1979. Recommended General Methods for the Examination of Fish and Fish Products, Analyst, 104: 434-450.

AOAC. 1965. Official Methods of Analysis. Association of Official Analytical Chemists. $10^{\text {th }}$ edition. Washington, D. C.

Bhotta, J. R.; Lauder, J. T. and Jewer, M. A. 1984. Effect of Methodology on TotalVolatile Basic Nitrogen (TVB-N) determination as an index of quality of fresh Atlantic cod (Gadus morhua). Journal of Food Science, 49: 734-736,750.

Bhuiyan, M. R. 1992. Proximate Biochemical Analysis and Spoilage pattern of Six Marine Fishes of the Bay of Bengal, M. Sc. Thesis, Institute of Marine Science and Fisheries, University of Chittagong, Chittagong.
Chakraborty, S. C.; M. N. Islam.; A. S. Khan. 1997. Study on the evaluation of the quality aspects of dry salted, wet salted and sun-dried Hilsa fish (Hilsa ilisha). Bangladesh Journal of Agricultural Science, 24(1): 71-79.

Clesceri, L. S.; Greenberg, A. E. and Trussed, R. R. 1989. Standard method for the examination of water and waste water. 17th ed. American Public Health Association. Washington D. C.. pp. 1-30, 40-175.

Composition, storage stability and fatty acid profiles of 5 common commercially available fish species in Oron/Local Govt. Nog. Food. Chem., 97: 490-497.

Connell, J. J. 1975. Intrinsic Quality. In: Control of Fish Quality. Fishing News Books Ltd. Farnham, Surrey, England. pp. 4-30.

Connell, J. J. 1980. Intrinsic Quality. In: Control of Fish Quality. (Second Edition). Fishing News Books Ltd. Farnham, Surrey, England. pp. 4-30.

DoF (Department of Fisheries). 2015. 'National Fish Week-2015'. Publication on the occasion of Fish Week 2015. Department of Fisheries, Ministry of Fisheries and Livestock, Govt. of the People's Republic of Bangladesh, Dhaka, Bangladesh. $144 \mathrm{p}$.

Eboh, L.; Mepba, H. D. and Ekpo, M. B. 2006. Heavy metal contamination and processing effects on the

Gruger, E. H. 1972. Chromatographic analysis of volatile amines in marine fish. Journal of Agricultural and Food Chemistry, 20: 781-785.

Horner, W. F. A. 1992. Preservation of fish by curing (drying, salting and smoking). In: Fish Processing Technology, G. M. Hall. (Editor). Blackie Academic and Professional, Glassgow, U. K. pp. 31-71.

Howgate, P. A.; Johnson, P. and Whittle, K. J. 1992. Multilingual Guide to EC freshness grades for fishery products. Torry Research Station, Aberdeen. Food Safety Directorate, Ministry of Agriculture, Fisheries and Food, UK. 9 p.

Keay, J. N. and Hardy, R. 1972. The separation of aliphatic amines in dilute aqueous solution by gas chromatography and application of this technique to quantitative analysis of tri- and dimethyl amines in fish. Journal of the Science of Food and Agriculture, 23: 9-19.

Love, R. M. 1992. Biochemical dynamics and the quality of fresh and frozen fish. In: "Fish Processing Technology". G. M. Hall (Editor). Blackie Academic and Professional, Glassgow, UK. pp 1-30.

Mansur, M. A. 1995. Biochemical and Textural aspects of the ripening of pickled herring (Clupea harengus).Ph.D. Thesis. University of Hull, England, UK. 229 p.

Mansur, M. A.; Chakraborty, S. C.; Azam, A. K. M. S.; Rahman, A. K. M. and Rahman, S. 2016. 708y]i9h-p/i-Evaluation of quality and safety aspect of chilled prawn crobrachium rosenbergii) during storage at -200C. Indian Journal of GeoMarine Sciences, 45 (9): 1188-1194. 
Mansur, M. A.; Chakraborty, S. C.; Rahman, S. M.; Rahman, A. K. M. F.; Rahman, S. and Uga, S. 2017. Quality aspect and heavy metal concentration of five important fishes of the Brahmaputra river in Mymensingh district of Bangladesh. The Research Society for Dietary Habits, 37(2): 27-36.

Mansur, M. A.; Islam, M. N. Chakraborty, S. C; Chaity, F. 1990. A comparative study on the quality of traditional and solar tent dried fish. Bangladesh J. Fish., 13(1\&2): 33-39.

Mansur, M. A.; Rahman, M. S.; Khan, M. N. A.; Reza, M. S.; Sadia, L.; Wahab, R. 2014. Studies on the quality attributes and safety aspect of semifermented fish product. Indian Journal of GeoMarine Sciences, 43(6): 949-954.

Mansur, M. A.; Rahman, S.; Khan, M. N. A.; Reza, M. S.; Kamrunnahar; Uga, S. 2013. Study on the quality and safety aspect of three sun-dried fish. African Journal of Agricultural Research, 8 (41): 5149-5155.

Miller, A.; Scanlon, R. A.; Lee, J. S. and Libbey, L. M. 1972. Quantitative and selective gas chromatography of dimethyl and trimethylamine in fish. Journal of Agricultural and Food Chemistry, 20: 709-711.

Murray, C. K. and Gibson, D. M. 1972. An investigation of the method of determining trimethylamine in fish muscle extracts by formation of the picrate salt I. Journal of Food Technology, 7: 35-46.

Parris, N. 1984. An improved fluorometric method for the determination of Ammonia and Volatile
Amines in meat tissue by High-performance liquid chromatography. Journal of Agricultural Food Chemistry, 32: 820-831.

Pravakar, P.; Mansur, M. A. and Asaduzzaman, M. 2013. Quality and Safety Aspect of Three SunDried Marine Fish Species: Chinese Pomfret (Stromateus chinensis), Bombay Duck (Harpodon neherius) and Ribbon Fish (Trichiurus haumela). World Journal of Zoology, 8(4): 381-387.

Ritskes, T. M. 1975. The gas chromatographic determination of trimethylamine and dimethylamine in fish, fishery products and other food stuffs. Journal of Food Technology, 10: 221228.

Ruiter, A. and Weseman, J. M. 1976. The automated determination of volatile bases (trimethylamine, dimethylamine and ammonia) in fish and shrimp. Journal of Food Technology, 11: 59-68.

Siddique, M. A. M. and M. Akter. 2011. Changes of nutritional value of three marine dry fishes (Johnius dussumieri, Harpodon nehereus and Lepturacanthus savala) during storage. Food and Nutrition Sciences, 2: 1082-1087.

Ward, D. R.; Finne, G. and Nickelson, R. 1979. Use of a specific- ion electrode (ammonia) in determining the quality of shrimp. Journal of Food Science, 44: 1052-1057.

World Health Organization. 2001. Arsenic and arsenic compounds. (Second Edition). Environmental Health Criteria. Geneva. World Health Organization. 224 p. 